\title{
Varietal influence on the nutrient contents and their uptake by wheat
}

\author{
F. N. Nipa*, B. K. Saha, M. A. H. Chowdhury and M. N. Hassan ${ }^{1}$ \\ Department of Agricultural Chemistry, Bangladesh Agricultural University, Mymensingh-2202 and \\ ${ }^{1}$ Department of Agricultural Extension, Ministry of Agriculture, Bangladesh, *E-mail: nipaag.06@gmail.com
}

\begin{abstract}
A field experiment was carried out in the Light village of Netrokona Sadar during the period from December 2010 to March 2011 to study the performance of some wheat varieties in terms of nutrient contents and their uptake. The experiment comprised of five varieties of wheat viz. BARI Gam 25, Shatabdi, BARI Gam 26, Prodip and Bijoy. The experiment was laid out in a randomized complete block design with six replications. The nutrient contents and their uptake by wheat grain and straw were significantly influenced by the varieties. The highest N, P, K, S, Ca, B and Zn contents in grain were found in the variety BARI Gam 26 and the lowest N, K, S, Ca and Mg contents were found in the variety Shatabdi. The maximum N, P and S uptake by grain were recorded in the variety BARI Gam 26 . On the other hand, the highest $\mathrm{K}$ and $\mathrm{Zn}$ uptake by grain were obtained from the variety Prodip. The minimum $\mathrm{N}, \mathrm{K}, \mathrm{S}, \mathrm{Ca}$, $\mathrm{Mg}$ and $\mathrm{Zn}$ uptake by grain were recorded in the variety Shatabdi. In straw, the maximum N, P, K, S, Ca and B uptake were observed in the variety BARI Gam 26 and the minimum N, K, S, Ca and B uptake were found in the variety BARI Gam 25. On the basis of nutrient contents and their uptake, wheat variety BARI Gam 26 showed the best performance.
\end{abstract}

Keywords: Wheat, Variety, Nutrition

\section{Introduction}

Wheat is one of the most important cereal crops globally and is a staple food over 60 countries (Hussain and Shah, 2002). About one third of the world's population lives on wheat grain for their subsistence (Hanson et al., 1982). It is the second important cereal crop in Bangladesh after rice. Wheat covered 7.74 million hectare having a total production of 2.19 million tons of grain in 2005-2006 (BBS, 2006). Wheat is considered as utmost among the cereals due to the fact, that its grain contains protein with unique chemical and physical properties. Besides being a rich source of carbohydrates, it contains other valuable components such as protein and minerals ( $\mathrm{P}, \mathrm{K}, \mathrm{Ca}, \mathrm{Mg}, \mathrm{Fe}, \mathrm{B}$ and $\mathrm{Zn})$. It provides more protein and nutrients than any other cereal crops (Iqtidar et al., 2006). However, the global challenge for wheat nutrition is to increase grain yield while maintaining its protein and minerals (Tilman et al., 2002). Wheat yield and end-use quality depend upon the environment, genotype, and their interactions. Variety plays an important role in producing high yield of wheat because various varieties responded differently for the genotypic characters, input requirement, growth process and the prevailing environment during growing season. The efficiency of major nutrients in increasing wheat production has been well documented (Nisar and Rashid, 2003; Jarwar et al., 2005; Stewart et al., 2005; Panaullah et al., 2006; Saleque et al., 2006; Timsina et al., 2006). Wheat cultivars can differ in nutrient use efficiency as a result of differences in the absorption of nutrients (Rodgers and Barneix, 1988) and utilization (Van Sanford and MacKown, 1986). However, improved varieties are often developed without considering their ability to grow and yield under low soil nutrient status and have been selected for high yields under high nutrient input conditions (Wissum et al., 2009). Feil (1992) indicated that varieties producing large amount of biomass seemed to have more nutrient uptake efficiency, which could decrease nutrient utilization efficiency thereby also decreasing total nutrient use effeciency of modern varieties. Genetic variation highly influences the nutrient content and their uptake by plants (Singh and Arora, 2001). The present study compared the nutrient content and their uptake by most popular five BARI released wheat varieties of Bangladesh.

\section{Materials and Methods}

The experiment was conducted in a typical wheat growing soil at the "Light village" of Netrokona sadar during the period from December 2010 to March 2011. There were five wheat varieties considered as treatments to be tested. The varieties were BARI Gam 25, Shatabdi, BARI Gam 26, Prodip and Bijoy. The experiment was laid out in a randomized complete block design with six replications. Initial soil sample 
was collected and kept in a polyethylene bag for chemical analysis. The soil of the plots was silty loam textured having $\mathrm{pH} 6.49$, organic carbon $0.72 \%$, total $\mathrm{N} 0.12 \%$, available $\mathrm{P} 12.1 \mu \mathrm{g} \mathrm{g}^{-1}$ soil, exchangeable $\mathrm{K} 0.5 \mathrm{c} \mathrm{mol} \mathrm{kg}{ }^{-1}$ available S $9.28 \mu \mathrm{g} \mathrm{g}^{-1}$ soil. There were altogether 30 unit plots in the experiment. Each replication was divided into 5 unit plots. The net size of each unit plot area was $20 \mathrm{~m}^{2}(5 \mathrm{~m} \times 4 \mathrm{~m})$. The spaces between blocks and between plots were $1 \mathrm{~m}$ and $0.5 \mathrm{~m}$, respectively. Urea, TSP, MOP, gypsum, zinc sulphate, boric acid and cowdung were applied according to the Fertilizer Recommendation Guide (BARC, 2005). One third of urea and all other fertilizers were applied as basal during final land preparation prior to sowing. The remaining two thirds of urea was top dressed in two equal splits on 20 and 55 days after sowing (DAS) of the seeds. Seeds were sown on December 2, 2010. Weeding, irrigation and pesticide application were performed as and when necessary throughout the growing period. Agronomic characteristics were recorded; wheat grain and straw were collected and stored properly. N, P, K, S, Ca, Mg, B and Zn contents were determined from plant samples following standard methods that semi-micro kjeldahl method (Jackson, 1973), colorimetric method (Page et al., 1982), flame emission spectrophotometric method (Ghosh et al., 1983), turbidimetrically (Tandon, 1965), complexometric method (Page et al., 1982), Azomethine $-\mathrm{H}$ and atomic absorption spectrophotometric method as described by Page et al. (1982), respectively. The uptake of $\mathrm{N}, \mathrm{P}, \mathrm{K}, \mathrm{S}, \mathrm{Ca}, \mathrm{Mg}$, B and Zn were calculated by multiplying the concentration of the nutrient in the grain and straw samples with their corresponding yields. Analysis of variance was done with the help of computer package program MSTAT according to Gomez and Gomez (1984) and the mean differences among the treatments were adjudged by DMRT and LSD.

\section{Results and Discussion}

\section{Varietal influence on the nutrient content of wheat}

Nitrogen: Grain N content was significantly affected by different varieties (Table 1 ). The highest $\mathrm{N}$ content (2.013) was found in the variety BARI Gam 26. The lowest N $(1.420 \%)$ was measured in the variety Satabdi. In straw, the highest N (0.521\%) was recorded in BARI Gam 26 which was statistically identical with the variety Prodip (0.501\%). The lowest content $(0.406 \%) \mathrm{N}$ was recorded in the variety BARI Gam 25 which was statistically identical to the variety Satabdi $(0.407 \%)$. This difference might be due to the fertility status of the plots. The finding for $\mathrm{N}$ content agreed with the result obtained by Ramu (2008).

Phosphorus: Significant variation was found in $\mathrm{P}$ content of grain (Table 1). The highest $\mathrm{P}$ content $(0.404 \%)$ was found in the variety BARI Gam 26 . The lowest content $(0.256 \%)$ P was observed in the variety Bijoy which was statistically identical with the variety Satabdi $(0.299 \%)$ and the variety BARI Gam $25(0.306 \%)$. In straw, the highest $P(0.201 \%)$ was recorded in the variety BARI Gam 26 . The lowest $P$ content $(0.096 \%)$ was recorded in the variety Satabdi which was statistically identical with the variety BARI Gam $25(0.140 \%)$ and Bijoy (0.152\%). Nutrient uptake capacity of the varieties might be the reason for this difference. This result was in accordance with that of Norton (2009).

Potossium: Significant difference was found in $\mathrm{K}$ content of grain (Table 1 ). The highest $\mathrm{K}$ content $(0.411 \%)$ was found in the variety BARI Gam 26 which was statistically identical with the varieties BARI Gam 25 (0.380\%), Prodip (0.393\%) and Bijoy (0.374\%). The lowest K content $(0.345 \%)$ was recorded in the variety Satabdi. In straw the highest K content (1.32\%) was recorded in the variety BARI Gam 26 . The lowest K content $(1.13 \%)$ was recorded in the variety BARI Gam 25, which was statistically identical with the varieties Bijoy (1.15\%) and Prodip (1.19\%). This difference might be due to the fertility status of the plots and $\mathrm{K}$ fixation. The result revealed that $\mathrm{K}$ content varied in different varieties (Norton, 2009).

Sulphur: Grain $S$ content was significantly influenced by variety (Table 2 ). The highest $S$ content $(0.232 \%)$ was found in the variety BARI Gam 26 which was statistically identical with the varieties Prodip (0.215\%), BARI Gam $25(0.193 \%)$ and Bijoy (0.176\%). The lowest value (0.165\%) was observed in the variety Satabdi. Effect of variety was insignificant on straw S content of wheat (Table 1). But numerically the highest value (0.140\%) was recorded in the variety BARI Gam 26, followed by Prodip (0.115\%), Bijoy (0.114\%), and BARI Gam $25(0.088 \%)$. The lowest value (0.081\%) was observed in the variety Satabdi. S uptake capacity of wheat varieties might affect on $\mathrm{S}$ content. This finding was commensurated with the observation made by Norton (2009). 
Table 1. Varietal influence on $\mathrm{N}, \mathrm{P}$ and $\mathrm{K}$ contents of wheat

\begin{tabular}{|l|c|c|c|c|c|c|}
\hline \multirow{2}{*}{ Treatment } & \multicolumn{2}{|c|}{ Nitrogen (\%) } & \multicolumn{2}{c|}{ Phosphorus (\%) } & \multicolumn{2}{c|}{ Potassium (\%) } \\
\cline { 2 - 7 } & Grain & Straw & Grain & Straw & Grain & Straw \\
\hline BARI Gam 25 & $1.68 \mathrm{c}$ & $0.406 \mathrm{c}$ & $0.306 \mathrm{bc}$ & $0.140 \mathrm{ab}$ & $0.380 \mathrm{ab}$ & $1.13 \mathrm{c}$ \\
\hline Satabdi & $1.42 \mathrm{~d}$ & $0.407 \mathrm{c}$ & $0.299 \mathrm{bc}$ & $0.096 \mathrm{~b}$ & $0.345 \mathrm{~b}$ & $1.21 \mathrm{~b}$ \\
\hline BARI Gam 26 & $2.01 \mathrm{a}$ & $0.521 \mathrm{a}$ & $0.404 \mathrm{a}$ & $0.201 \mathrm{a}$ & $0.411 \mathrm{a}$ & $1.32 \mathrm{a}$ \\
\hline Prodip & $1.79 \mathrm{~b}$ & $0.501 \mathrm{ab}$ & $0.329 \mathrm{~b}$ & $0.160 \mathrm{a}$ & $0.393 \mathrm{ab}$ & $1.19 \mathrm{bc}$ \\
\hline Bijoy & $1.61 \mathrm{c}$ & $0.445 \mathrm{bc}$ & $0.256 \mathrm{c}$ & $0.152 \mathrm{ab}$ & $0.374 \mathrm{ab}$ & $1.15 \mathrm{bc}$ \\
\hline CV \% & 3.40 & 5.41 & 5.58 & 21.84 & 4.20 & 2.82 \\
\hline LSD & 0.103 & 0.059 & 0.059 & 0.059 & 0.059 & 0.059 \\
\hline
\end{tabular}

Table 2. Varietal influence on $\mathrm{S}, \mathrm{Ca}$ and $\mathrm{Mg}$ contents of wheat

\begin{tabular}{|c|c|c|c|c|c|c|}
\hline \multirow[t]{2}{*}{ Treatment } & \multicolumn{2}{|c|}{ Sulphur (\%) } & \multicolumn{2}{|c|}{ Calcium (\%) } & \multicolumn{2}{|c|}{ Magnesium (\%) } \\
\hline & Grain & Straw & Grain & Straw & Grain & Straw \\
\hline BARI Gam 25 & $0.193 \mathrm{ab}$ & 0.088 & $0.367 \mathrm{ab}$ & 0.290 & $0.427 \mathrm{bc}$ & $0.340 \mathrm{~b}$ \\
\hline Satabdi & $0.165 \mathrm{~b}$ & 0.081 & $0.327 \mathrm{~b}$ & 0.280 & $0.408 \mathrm{c}$ & $0.290 \mathrm{~b}$ \\
\hline BARI Gam 26 & $0.232 \mathrm{a}$ & 0.140 & $0.440 \mathrm{a}$ & 0.367 & $0.480 \mathrm{ab}$ & $0.410 \mathrm{a}$ \\
\hline Prodip & $0.215 \mathrm{ab}$ & 0.115 & $0.370 \mathrm{ab}$ & 0.367 & $0.491 \mathrm{a}$ & $0.313 \mathrm{~b}$ \\
\hline Bijoy & $0.176 a b$ & 0.114 & $0.410 \mathrm{ab}$ & 0.340 & $0.523 \mathrm{a}$ & $0.433 \mathrm{a}$ \\
\hline CV \% & 5.30 & 8.04 & 11.35 & 14.04 & 3.73 & 8.76 \\
\hline LSD & 0.059 & 0.059 & 0.084 & 0.084 & 0.059 & 0.059 \\
\hline
\end{tabular}

Calcium: It was observed that $\mathrm{Ca}$ content in grain was expressively influenced by the treatments (Table 2). The highest Ca content $(0.440 \%)$ was found in the variety BARI Gam 26 , which was statistically identical with the variety Bijoy (0.410\%), Prodip (0.370\%) and BARI Gam $25(0.367 \%)$. The lowest value $(0.327 \%)$ was observed in the variety Satabdi. The Ca content of wheat straw was found statistically nonsignificant. The highest numerical value $(0.366 \%)$ was recorded in the variety BARI Gam 26 and Prodip, respectively. Numerically the lowest value $(0.280 \%)$ was recorded in the variety Satabdi. The findings for this character agreed with the result obtained by Norton (2009).

Magnesium: The grain Mg content was significantly affected by different treatments (Table 2). The highest value $(0.522 \%)$ was found in the variety Bijoy, which was identical with the variety Prodip $(0.491 \%)$ and BARI Gam $26(0.480 \%)$. The lowest value $(0.408 \%)$ was observed in the variety Satabdi, which was identical with the variety BARI Gam $25(0.427 \%)$. The content of $\mathrm{Mg}$ in wheat straw was found statistically significant. The highest $\mathrm{Mg}$ content $(0.433 \%)$ was recorded in the variety Bijoy, which was identical with the variety BARI Gam $26(0.410 \%)$. The lowest value $(0.290 \%)$ was recorded in the variety Satabdi, which was identical with the variety Prodip (0.313\%) and BARI Gam 25 (0.340\%). Nutrient uptake capacity of the varieties might be the reason for this difference.

Boron: The content of $B$ in grain was significantly affected by different treatments (Table 3 ). The highest value $\left(18.63 \mathrm{mg} \mathrm{kg}^{-1}\right)$ was found in the variety BARI Gam 26, which was identical with the variety Bijoy $\left(18.20 \mathrm{mg} \mathrm{kg}^{-1}\right)$. The lowest value $\left(15.50 \mathrm{mg} \mathrm{kg}^{-1}\right)$ was observed in the variety BARI Gam 25 . In straw, significant result was found. The highest B content $\left(17.20 \mathrm{mg} \mathrm{kg}^{-1}\right)$ was recorded in the variety BARI Gam 26 , followed by Bijoy $\left(16.83 \mathrm{mg} \mathrm{kg}^{-1}\right)$ and Prodip $\left(16.13 \mathrm{mg} \mathrm{kg}^{-1}\right)$. The lowest B content $\left(14.77 \mathrm{mg} \mathrm{kg}^{-1}\right)$ was recorded in the variety BARI Gam 25 preceded by Satabdi $\left(15.50 \mathrm{mg} \mathrm{kg}^{-1}\right)$. B uptake capacity of the varieties might be the reason for this difference. Norton (2009) also found similar result.

Zinc: The status of $\mathrm{Zn}$ in grain was significantly affected by different treatments (Table 3 ). The highest value $\left(35.53 \mathrm{mg} \mathrm{kg}^{-1}\right)$ was found in the variety BARI Gam 26 which was identical with the variety Prodip $\left(35.28 \mathrm{mg} \mathrm{kg}^{-1}\right)$. The lowest value $\left(30.05 \mathrm{mg} \mathrm{kg}^{-1}\right)$ was observed in the variety Bijoy, which was identical with the variety Satabdi $\left(30.08 \mathrm{mg} \mathrm{kg}^{-1}\right)$ and BARI Gam $25\left(30.55 \mathrm{mg} \mathrm{kg}^{-1}\right)$. The content of $\mathrm{Zn}$ in wheat straw differed significantly among different treatments. The highest $\mathrm{Zn}$ content $\left(31.20 \mathrm{mg} \mathrm{kg} \mathrm{gas}^{-1}\right)$ was recorded in the variety BARI Gam 26 which was identical with the treatment Prodip $\left(30.30 \mathrm{mg} \mathrm{kg}^{-1}\right)$ and Satabdi $\left(29.77 \mathrm{mg} \mathrm{kg}^{-1}\right)$. The lowest value $\left(26.33 \mathrm{mg} \mathrm{kg}^{-1}\right)$ was recorded in the variety Bijoy. The findings for this character agreed with the result obtained by Hajra et al. (2006). 
Table 3. Varietal influence on $B$ and $\mathrm{Zn}$ contents of wheat

\begin{tabular}{|l|c|c|c|c|}
\hline \multirow{2}{*}{ Treatment } & \multicolumn{2}{|c|}{ Boron $\left(\mathrm{mg} \mathrm{kg}^{-1}\right)$} & \multicolumn{2}{c|}{ Zinc $\left(\mathrm{mg} \mathrm{kg}^{-1}\right)$} \\
\cline { 2 - 5 } & Grain & Straw & Grain & Straw \\
\hline BARI Gam 25 & $15.50 \mathrm{~d}$ & $14.77 \mathrm{c}$ & $30.55 \mathrm{~b}$ & $29.43 \mathrm{~b}$ \\
\hline Satabdi & $16.53 \mathrm{c}$ & $15.50 \mathrm{bc}$ & $30.08 \mathrm{~b}$ & $29.77 \mathrm{ab}$ \\
\hline BARI Gam 26 & $18.63 \mathrm{a}$ & $17.20 \mathrm{a}$ & $35.53 \mathrm{a}$ & $31.20 \mathrm{a}$ \\
\hline Prodip & $17.33 \mathrm{~b}$ & $16.13 \mathrm{ab}$ & $35.28 \mathrm{a}$ & $30.30 \mathrm{ab}$ \\
\hline Bijoy & $18.20 \mathrm{a}$ & $16.83 \mathrm{a}$ & $30.05 \mathrm{~b}$ & $26.33 \mathrm{c}$ \\
\hline CV \% & 1.96 & 4.00 & 1.50 & 2.87 \\
\hline LSD & 0.635 & 1.21 & 0.914 & 1.59 \\
\hline
\end{tabular}

Varietal influence on the uptake by wheat

Nitrogen: Grain $\mathrm{N}$ uptake was significantly affected by different varieties (Table 4). The maximum $\mathrm{N}$ uptake (74.65 kg ha ${ }^{-1}$ ) was found in the variety BARI Gam 26 which was statistically identical with the variety prodip $\left(71.48 \mathrm{~kg} \mathrm{ha}^{-1}\right)$. The lowest $\mathrm{N}$ uptake $\left(51.13 \mathrm{~kg} \mathrm{ha}^{-1}\right)$ was found in the variety Satabdi. Again in straw N uptake was influenced significantly. The highest N uptake was found in BARI Gam 26 (25.06 $\left.\mathrm{kg} \mathrm{ha}^{-1}\right)$ which was statistically identical with the variety prodip $\left(23.75 \mathrm{~kg} \mathrm{ha}^{-1}\right)$. The lowest $\mathrm{N}$ uptake $(18.72$ $\mathrm{kg} \mathrm{ha}^{-1}$ ) was found in the variety BARI Gam 25 which was statistically identical with Satabdi (20.81 kg $\mathrm{ha}^{-1}$ ) and Bijoy $\left(20.96 \mathrm{~kg} \mathrm{ha}^{-1}\right)$. Genetic variation of wheat varieties might be the factor of different level of $\mathrm{N}$ uptake (Ramu, 2008).

Phosphorus: $P$ uptake by grain was significantly affected by different varieties (Table 4). The maximum $P$ uptake $\left(15.01 \mathrm{~kg} \mathrm{ha}^{-1}\right)$ was found in the variety BARI Gam 26 . The minimum value $\left(9.661 \mathrm{~kg} \mathrm{ha}^{-1}\right)$ was found in the variety Bijoy which was statistically identical with the variety Satabdi $\left(10.77 \mathrm{~kg} \mathrm{ha}^{-1}\right)$. Again in straw, $P$ uptake was influenced significantly. The highest $P$ uptake $\left(9.66 \mathrm{~kg} \mathrm{ha}^{-1}\right)$ was found in the variety BARI Gam 26. The lowest $P$ uptake $\left(4.91 \mathrm{~kg} \mathrm{ha}^{-1}\right)$ was found in the variety Satabdi which was statistically identical with the variety BARI Gam $25\left(6.45 \mathrm{~kg} \mathrm{ha}^{-1}\right)$. Norton (2009) found that the difference in P uptake might be due to the genetic variation of wheat varieties.

Potassium: Grain $\mathrm{K}$ uptake was significantly affected by different varieties (Table 4). The maximum uptake (15.74 $\mathrm{kg} \mathrm{ha}^{-1}$ ) was found in the variety Prodip, which was statistically identical with the variety BARI Gam $26\left(15.26 \mathrm{~kg} \mathrm{ha}^{-1}\right)$. The minimum value $\left(12.42 \mathrm{~kg} \mathrm{ha}^{-1}\right)$ was found in the variety Satabdi. Again in straw, $\mathrm{K}$ uptake was 4 times higher than grain $\mathrm{K}$ uptake. The highest $\mathrm{K}$ uptake $\left(63.60 \mathrm{~kg} \mathrm{ha}^{-1}\right)$ was found in variety BARI Gam 26, which was statistically identical with the variety Satabdi $\left(61.88 \mathrm{~kg} \mathrm{ha}^{-1}\right)$. The lowest value (51.91 $\mathrm{kg} \mathrm{ha}^{-1}$ ) was found in the variety BARI Gam 25 , which was statistically identical with the variety Prodip $\left(54.23 \mathrm{~kg} \mathrm{ha}^{-1}\right)$. Similar result was also observed by Norton (2009).

Sulphur: Significant variation was found in $S$ uptake by grain. The maximum uptake $\left(8.62 \mathrm{~kg} \mathrm{ha}^{-1}\right)$ was found in the variety BARI Gam 26 , which was statistically identical with the variety Prodip $\left(8.60 \mathrm{~kg} \mathrm{ha}^{-1}\right)$. The minimum value $\left(5.95 \mathrm{~kg} \mathrm{ha}^{-1}\right)$ was found in the variety Satabdi, which was statistically identical with the variety Bijoy $\left(6.67 \mathrm{~kg} \mathrm{ha}^{-1}\right)$. Again, significant result was found in S uptake by wheat straw. The highest $S$ uptake $\left(6.73 \mathrm{~kg} \mathrm{ha}^{-1}\right)$ was found in the variety BARI Gam 26 . The lowest S uptake $\left(4.09 \mathrm{~kg} \mathrm{ha}^{-1}\right)$ was found in the variety BARI Gam 25 which was statistically identical with the variety Satabdi $\left(4.13 \mathrm{~kg} \mathrm{ha}^{-1}\right)$.

Calcium: Significant difference was found in Ca uptake by grain. The maximum uptake $\left(16.40 \mathrm{~kg} \mathrm{ha}^{-1}\right)$ was found in the variety Prodip, which was statistically identical with the variety BARI Gam $26(16.32 \mathrm{~kg}$ $\left.\mathrm{ha}^{-1}\right)$, Bijoy $\left(13.96 \mathrm{~kg} \mathrm{ha}^{-1}\right)$ and BARI Gam $25\left(13.60 \mathrm{~kg} \mathrm{ha}^{-1}\right)$. The minimum value $\left(11.76 \mathrm{~kg} \mathrm{ha}^{-1}\right)$ was found in the variety Satabdi, which was statistically identical with the variety BARI Gam 25 (13.60 kg ha') and Bijoy $\left(13.96 \mathrm{~kg} \mathrm{ha}^{-1}\right)$. Again, significant result was found in Ca uptake by straw. The highest uptake $\left(17.62 \mathrm{~kg} \mathrm{ha}^{-1}\right)$ was found in the variety BARI Gam 26 which was statistically identical with the variety Prodip (17.36 kg ha-1). The lowest Ca uptake $\left(12.90 \mathrm{~kg} \mathrm{ha}^{-1}\right.$ ) was found in the variety BARI Gam 25 which was statistically similar with Satabdi $\left(14.83 \mathrm{~kg} \mathrm{ha}^{-1}\right)$ and Bijoy $\left(15.99 \mathrm{~kg} \mathrm{ha}^{-1}\right)$. 
Table 4. Varietal influence on $\mathrm{N}, \mathrm{P}$ and $\mathrm{K}$ uptake by wheat grain and straw

\begin{tabular}{|l|c|c|c|c|c|c|}
\hline \multirow{2}{*}{ Treatment } & \multicolumn{2}{|c|}{ Nitrogen $\left(\mathrm{kg} \mathrm{ha}^{-1}\right)$} & \multicolumn{2}{c|}{ Phosphorus $\left(\mathrm{kg} \mathrm{ha}^{-1}\right)$} & \multicolumn{2}{c|}{ Potassium $\left(\mathrm{kg} \mathrm{ha}^{-1}\right)$} \\
\cline { 2 - 7 } & Grain & Straw & Grain & Straw & Grain & Straw \\
\hline BARI Gam 25 & $62.31 \mathrm{~b}$ & $18.72 \mathrm{~b}$ & $11.36 \mathrm{c}$ & $6.45 \mathrm{~b}$ & $14.09 \mathrm{~b}$ & $51.91 \mathrm{c}$ \\
\hline Satabdi & $51.13 \mathrm{c}$ & $20.81 \mathrm{~b}$ & $10.77 \mathrm{~cd}$ & $4.91 \mathrm{~b}$ & $12.42 \mathrm{c}$ & $61.88 \mathrm{a}$ \\
\hline BARI Gam 26 & $74.65 \mathrm{a}$ & $25.06 \mathrm{a}$ & $15.01 \mathrm{a}$ & $9.66 \mathrm{a}$ & $15.26 \mathrm{ab}$ & $63.60 \mathrm{a}$ \\
\hline Prodip & $71.48 \mathrm{a}$ & $23.75 \mathrm{a}$ & $13.18 \mathrm{~b}$ & $7.61 \mathrm{ab}$ & $15.74 \mathrm{a}$ & $54.23 \mathrm{bc}$ \\
\hline Bijoy & $60.64 \mathrm{~b}$ & $20.96 \mathrm{~b}$ & $9.66 \mathrm{~d}$ & $7.14 \mathrm{ab}$ & $14.14 \mathrm{~b}$ & $56.19 \mathrm{~b}$ \\
\hline CV \% & 3.50 & 5.32 & 5.56 & 21.60 & 4.20 & 2.81 \\
\hline LSD & 4.21 & 2.19 & 1.25 & 2.91 & 1.13 & 3.04 \\
\hline
\end{tabular}

Magnesium: Magnesium uptake by grain was significantly affected by different treatments (Table 5 ). Maximum uptake (19.73 kg ha ${ }^{-1}$ ) was observed in the variety Bijoy which was statistically similar with Prodip (19.65 kg ha $\left.{ }^{-1}\right)$. The lowest Mg uptake $\left(14.69 \mathrm{~kg} \mathrm{ha}^{-1}\right)$ was found in the variety Satabdi proceeded by BARI Gam $25\left(15.85 \mathrm{~kg} \mathrm{ha}^{-1}\right)$. Again, Mg uptake by wheat straw was found statistically significant. The highest uptake $\left(20.38 \mathrm{~kg} \mathrm{ha}^{-1}\right)$ was found in the variety Bijoy, which was identical with the variety BARI Gam $26\left(19.70 \mathrm{~kg} \mathrm{ha}^{-1}\right)$. The lowest value $\left(14.83 \mathrm{~kg} \mathrm{ha}^{-1}\right)$ was found in the variety Satabdi followed by Prodip (14.84 kg ha $\left.{ }^{-1}\right)$ and BARI Gam 25 (15.66 kg ha'). Norton (2009) also found similar result.

Table 5. Varietal influence on $\mathrm{S}, \mathrm{Ca}$ and Mg uptake by wheat grain and straw

\begin{tabular}{|l|c|c|c|c|c|c|}
\hline \multirow{2}{*}{ Treatment } & \multicolumn{2}{|c|}{ Sulphur $\left(\mathrm{kg} \mathrm{ha}^{-1}\right)$} & \multicolumn{2}{c|}{ Calcium $\left(\mathrm{kg} \mathrm{ha}^{-1}\right)$} & \multicolumn{2}{c|}{ Magnesium $\left(\mathrm{kg} \mathrm{ha}^{-1}\right)$} \\
\cline { 2 - 7 } & Grain & Straw & Grain & Straw & Grain & Straw \\
\hline BARI Gam 25 & $7.171 \mathrm{~b}$ & $4.085 \mathrm{c}$ & $13.60 \mathrm{ab}$ & $12.90 \mathrm{~b}$ & $15.85 \mathrm{c}$ & $15.66 \mathrm{~b}$ \\
\hline Satabdi & $5.954 \mathrm{c}$ & $4.125 \mathrm{c}$ & $11.76 \mathrm{~b}$ & $14.83 \mathrm{ab}$ & $14.69 \mathrm{c}$ & $14.83 \mathrm{~b}$ \\
\hline BARI Gam 26 & $8.615 \mathrm{a}$ & $6.726 \mathrm{a}$ & $16.32 \mathrm{a}$ & $17.62 \mathrm{a}$ & $17.81 \mathrm{~b}$ & $19.70 \mathrm{a}$ \\
\hline Prodip & $8.602 \mathrm{a}$ & $5.445 \mathrm{~b}$ & $16.40 \mathrm{a}$ & $17.36 \mathrm{a}$ & $19.65 \mathrm{a}$ & $14.84 \mathrm{~b}$ \\
\hline Bijoy & $6.667 \mathrm{bc}$ & $5.360 \mathrm{~b}$ & $13.96 \mathrm{ab}$ & $15.99 \mathrm{ab}$ & $19.73 \mathrm{a}$ & $20.38 \mathrm{a}$ \\
\hline CV \% & 5.33 & 8.14 & 11.11 & 13.83 & 3.67 & 8.85 \\
\hline LSD & 0.743 & 0.789 & 3.01 & 4.09 & 1.21 & 2.84 \\
\hline
\end{tabular}

Boron: Significant result was found in B uptake by wheat grain (Table 6). The maximum uptake (6.95 $\mathrm{kg}$ $\left.\mathrm{ha}^{-1}\right)$ was found in the variety Bijoy, which was identical with the variety BARI Gam $26\left(6.91 \mathrm{~kg} \mathrm{ha}^{-1}\right)$ and prodip $\left(6.87 \mathrm{~kg} \mathrm{ha}^{-1}\right)$. The minimum value $\left(5.75 \mathrm{~kg} \mathrm{ha}^{-1}\right)$ was found in the variety BARI Gam 25 . Again in straw, the value ranged from 6.80 to $8.27 \mathrm{~kg} \mathrm{ha}^{-1}$. The highest uptake $\left(8.27 \mathrm{~kg} \mathrm{ha}^{-1}\right)$ was found in the variety BARI Gam 26 which was identical with the variety Satabdi $\left(7.93 \mathrm{~kg} \mathrm{ha}^{-1}\right)$ and Bijoy $\left(7.92 \mathrm{~kg} \mathrm{ha}^{-1}\right)$. The lowest value $\left(6.80 \mathrm{~kg} \mathrm{ha}^{-1}\right)$ was found in the variety BARI Gam 25.

Zinc: Zn uptake by grain differed significantly (Table 6). The maximum Zn uptake (14.11 $\mathrm{kg} \mathrm{ha}^{-1}$ ) was found in the variety Prodip. The minimum $\mathrm{Zn}$ uptake $\left(10.83 \mathrm{~kg} \mathrm{ha}^{-1}\right)$ was found in the variety Satabdi. In straw, Zn uptake ranged from 12.38 to $15.22 \mathrm{~kg} \mathrm{ha}^{-1}$. The highest uptake $\left(15.22 \mathrm{~kg} \mathrm{ha}^{-1}\right)$ was found in the variety Satabdi, which was identical with the variety BARI Gam $26\left(14.99 \mathrm{~kg} \mathrm{ha}^{-1}\right)$. The lowest uptake $\left(12.38 \mathrm{~kg} \mathrm{ha}^{-1}\right)$ by straw was found in the variety Bijoy. Hajra et al. (2006) also observed similar result.

Table 6. Varietal influence on $B$ and $Z n$ uptake by wheat grain and straw

\begin{tabular}{|l|c|c|c|c|}
\hline \multirow{2}{*}{ Treatment } & \multicolumn{2}{|c|}{ Boron $\left(\mathrm{kg} \mathrm{ha}^{-1}\right)$} & \multicolumn{2}{c|}{ Zinc $\left(\mathrm{kg} \mathrm{ha}^{-1}\right)$} \\
\cline { 2 - 5 } & Grain & Straw & Grain & Straw \\
\hline BARI Gam 25 & $5.749 \mathrm{~b}$ & $6.803 \mathrm{c}$ & $11.33 \mathrm{c}$ & $13.56 \mathrm{c}$ \\
\hline Satabdi & $5.954 \mathrm{~b}$ & $7.927 \mathrm{ab}$ & $10.83 \mathrm{~d}$ & $15.22 \mathrm{a}$ \\
\hline BARI Gam 26 & $6.909 \mathrm{a}$ & $8.266 \mathrm{a}$ & $13.17 \mathrm{~b}$ & $14.99 \mathrm{ab}$ \\
\hline Prodip & $6.869 \mathrm{a}$ & $7.639 \mathrm{~b}$ & $14.11 \mathrm{a}$ & $14.35 \mathrm{~b}$ \\
\hline Bijoy & $6.935 \mathrm{a}$ & $7.915 \mathrm{ab}$ & $11.34 \mathrm{c}$ & $12.38 \mathrm{~d}$ \\
\hline CV \% & 1.96 & 3.93 & 1.52 & 2.83 \\
\hline LSD & 0.238 & 0.571 & 0.347 & 0.750 \\
\hline
\end{tabular}




\section{Conclusion}

The highest values of most of nutrient contents and uptake by wheat grain and straw were obtained from the variety BARI Gam 26 which was identical with the nutrients of the variety Bijoy. In contrast, the highest $\mathrm{K}$ and $\mathrm{Zn}$ contents and their uptake were found in the variety Prodip. Depending on the nutritional values of the test varieties, they can be ranked as BARI Gam 26> Bijoy>Prodip>BARI Gam 25>Satabdi. The overall results of this study suggest that farmers can be advised to cultivate BARI Gam 26 for getting nutritious wheat in the study area.

\section{References}

BARC (Bangladesh Agricultural Research Council) 2005. Fertilizer Recommendation Guide. New Airport Road, Farmgate, Dhaka. PP.71-72.

BBS. 2006. Monthly Statistical Bulletin, Bangladesh Bureau of Statistics, Stat. Div. Ministry of Planning, Govt. People's Republic of Bangladesh. pp. 54-55.

Feil, B. 1992. Breeding progress in small grain cereals- a comparison of old and modern cultivars. Plant Breeding. 108, 1-11.

Ghosh, A.B., Bajaj, J.C., Hasan, R. and Singh, D. 1983. Soil and Water Testing Method.A Laboratory Manual, Division of Soil Science and Agricultural Chemisiry, IARI, New Delhi, India. P. 221-226.

Gomez, K.A. and Gomez, A.A. 1984. Statistical Procedures for Agricultural Research. Second edn. John Willey and Sons, New York. pp. 97-411.

Hanson, H., Bolaugh, N.E. and Anderson, R.G. 1982. Wheat in the third world. West view press Inc. Boulder, Colorado, USA. p. 13.

Hajra, K., Zia, U.H. and Ali, A.M. 2006. Yield and micronutrients content of bread wheat (Triticum aestivum) under a multinutrient fertilizer -Hal-Tonic. Institute of Soil and Environmental Sciences, University of Agriculture, Faisalabad-38040, Pakistan.

Hussain, M.I. and Shah, S.H. 2002. Growth, yield and quality response of three wheat (Triticum aestivum L.) varieties to different levels of N, P and K. Int. J. Agri. and Bio. 4(3): 362-364.

Iqtidar, H., Khan, M. A. and Khan, E. A. 2006. Bread wheat varieties as influenced by different nitrogen levels. J. Zhejiang Univ. Sci. 70-78.

Jackson, M.L. 1973. Soil Chemical Analysis. Prentice Hall of India Pvt. Ltd., New Delhi. p. 151-154.

Jarwar, A.K., Memon, K.S. and Hassan, Z.U. 2005. Influence of the source and rate of nitrogenous fertilizer and irrigation depth on fertilizer N recovery and grain yield of wheat. J. Agri. Soc. Sci., 1(2): 105-108.

Norton, R. 2009. Grain Nutrient Concentrations - Report on a survey from 70 NVT wheat sites. International Plant Nutrition Institute, Australia and New Zealand. 5(6):44-46.

Nisar, A. and Rashid. M. 2003. Fertilizers and Their Use in Pakistan. Extension Bulletin. Third edn. NFDC, Islamabad.

Page, A.L., Miller, R.H. and Keeney, D.R. 1982. Methods of Soil Analysis. Part 11. American Soc. Agron., inc. Madi, USA.

Panaullah, G.M., Timsina, J., Saleque, M.A., Ishaque, M., Pathan, A.B.M.B.U., Connor, D.J., Saha, P.K., Quayyum, M.A., Humphreys, E. and Meisner, C.A. 2006. Nutrient uptake and apparent balances for rice wheat sequences. III. Potassium. J. Plant Nut. 29:173-87.

Ramu, N. 2008. Nitrogen management in wheat under irrigated condition. MS thesis. Department of Agronomy, College of Agriculture, Dharwad University of Agricultural Sciences, Dharwad.

Rodgers, C.O. and Barneix, A.J. 1988. Cultivar differences in the rate of nitrate uptake by intact wheat plants as related to growth rate. Physiologia Plantarum. 72:121-126.

Saleque, M.A., Timsina, J., Panaullah, G. M., Ishaque, M., Pathan, A.B.M.BU., Connor, D.J., Saha, P.K., Quayyum, M.A., Humphreys, E. and C.A. Meisner, 2006. Nutrient uptake and apparent balances for ricewheat sequences. II. Phosphorus. J. Plant Nut. 29:157-72.

Singh, V.P. and Arora, A. 2001. Intraspecific variation in nitrogen uptake and nitrogen utilization efficiency in wheat (Triticum aestivum L.). Crop Sci. 186:239-244.

Stewart, W.M., Dibb, D.W., Johnston, A.E. and Smyth, T.J. 2005. The contribution of commercial fertilizer nutrients to food production. Agron. J. 97:1-6.

Tandon, H.L.S. 1995. Methods of Analysis of Soils, Plants, Water and Fertilizers $2^{\text {nd }}$ edn. Fertilizer Development and Consultation Organization, New Delhi. P.44-45.

Tilman, D., Cassman, K.G., Matson, P.A., Naylor, R. and Polasky, S. 2002. Agricultural sustainability and intensive production practices. Nature. 418:671-677.

Timsina, J., Panaullah, G.M., Saleque, M.A., Ishaque, M., Pathan, A.B.M.B.U., Quayyum, M.A. Connor, D.J., Sana, P.K. Humphreys, E. and Meisner, C.A. 2006. Nutrient uptake and apparent balances for rice wheat sequences. I. Nitrogen. J. Plant Nut. 29:137-55.

Van Sanford, D.A. and MacKown, C.T. 1986. Variation in nitrogen use efficiency among soft red winter wheat genotypes. Theor. Appl. Genet. 72:158-163.

Wissum, M., Mazzola, M. and Picard, C. 2009. Novel approaches in plant breeding for Rhizosphere related traits. Plant Soil. 321:409-430. 